\title{
ОСОБЕННОСТИ ПРОБЛЕМ ПРАВОВОЙ ОХРАНЫ ИНДИВИДУАЛЬНОГО ХУДОЖЕСТВЕННОГО СТИЛЯ КАК ОБЪЕКТА ИНТЕЛЛЕКТУАЛЬНОЙ СОБСТВЕННОСТИ
}

\section{FEATURES OF THE PROBLEMS OF LEGAL PROTECTION OF INDIVIDUAL ARTISTIC STYLE AS AN OBJECT OF INTELLECTUAL PROPERTY}

\section{Bogatova}

Summary. The concept of intellectual property is interpreted as a set of exclusive rights of a personal and property nature to the results of intellectual activity, as well as to other objects equated to them, the specific list of which is established by the legislation of the state. Thus, according to the Civil Code of the Russian Federation, intellectual property is based on an exclusive right, which is a property right, and in certain cases - personal non-property and other rights (the right of succession, the right of access, etc.). Given the creative nature of works of art, the intellectual property regulations also apply to these products, but some features, such as the style of the work of art, are currently not regulated by law. Thus, the author comes to the conclusion that an individual artistic style should acquire a normative consolidation.

Keywords: artist, style, patent, copyright, legal protection, individual artistic style, intellectual property objects.

\author{
Богатова Ирина Александровна \\ Аспирант, Московский финансово-юридический \\ университет; помощник адвоката, Коллегия \\ адвокатов «Адвокат» \\ ira010187@rambler.ru
}

\begin{abstract}
Аннотация. Понятие интеллектуальной собственности трактуется как совокупность исключительных прав личного и имущественного характера на результаты интеллектуальной деятельности, а также на иные объекты, приравненные к ним, конкретный перечень которых устанавливается законодательством государства. Так, согласно ГК РФ в основе интеллектуальной собственности лежит исключительное право, которое представляет собой имущественное право, а в определенных случаях — личные неимущественные и иные права (право следования, право доступа и др.). Учитывая творческий характер художественных произведений, нормативное регулирование в сфере интеллектуальной собственности относится и к данным изделиям, однако некоторые особенности, такие как стиль художественного произведения, в настоящее время не урегулированы законодательством. Так, автор приходит к выводу, что индивидуальный художественный стиль должен обрести нормативное закрепление.
\end{abstract}

Ключевые слова: художник, стиль, патент, авторское право, правовая охрана, индивидуальный художественный стиль, объекты интеллектуальной собственности.

складывается ложное впечатление, что ничего адекватного нельзя сделать, чтобы остановить это, или им просто не хватает ноу-хау для защиты своих произведений. Однако, крайне важно, чтобы художники/живописцы были хорошо осведомлены о правах, имеющихся в их распоряжении для защиты своих творений. Кроме того, простое признание прав недостаточно для того, чтобы создатели могли защитить свои произведения от копирования, поэтому они должны быть хорошо осведомлены о существенных мерах в случае нарушения их произведений.

Отметим, что авторское право не защищает идеи, стили, данные, информацию, методы или концепции. Вместо этого авторское право защищает конкретное выражение идеи, которое было зафиксировано в материальной форме на любом носителе - записано ли оно или записано иным способом. Так, например, не существует авторского права на идею, выраженную в разговоре, если она не была записана, например, в письменной форме, на звукозаписи, на пленке или на флешке. 
Поэтому создатель не может полагаться на закон об авторском праве, если кто-то украл его идею, если она еще не была выражена в материальной форме. Другие области права могут обеспечивать защиту, например закон о конфиденциальной информации, договоры или патенты.

Произведение искусства/картина обладают такими отличиями как внешний вид и стиль, а также могут требовать определенных знаний, проявляемых в навыках, используемых для их производства.

В настоящее время, часто наблюдаются искажения и упрощения традиционных приемов художественного мастерства, ручной труд художников и мастеров часто подменяется механическим воспроизведением элементов декоративной отделки, снижается художественный уровень и качество продукции. В этой связи, актуальной становится необходимость понимания индивидуального художественного стиля как объекта интеллектуальной собственности.

Здесь стоит заметить, что ни в Гражданском кодексе РФ [1], ни в специальных законах или подзаконных актах, ни нормами международных конвенций и договоров понятие «стиль» как категория права не определено. То есть в правовом поле интеллектуальной собственности его определение отсутствует. Интеллектуальная собственность (ИС) - это термин, используемый для обозначения ряда юридических прав, которые защищают творения разума и творческие усилия. Патенты, товарные знаки и зарегистрированные образцы являются примерами ИС, как и авторское право.

Помимо защиты авторских прав и товарных знаков, произведения искусства или картины также могут быть защищены в соответствии с патентным законодательством. Авторские права защищают конструкции и методы ремесленников от подражания и копирования. Однако защита авторских прав не распространяется на определенные области искусства и ремесленной промышленности, например: функциональные особенности или основные методы их создания. Эти области, однако, подпадают под защиту патента с некоторыми исключениями.

Таким образом, на вопрос являются ли художественный стиль или творческая манера автора произведением - объектом права собственности, можно ответить, что не являются, поскольку отсутствует возможность изготовления, воспроизведения «в любой материальной форме ... или другой форме, которую может считывать компьютер», экземпляров художественного стиля или творческой манеры автора, как абсолютно точных их копий.
К особенностям проблем правовой охраны индивидуального художественного стиля как объекта интеллектуальной собственности, можно отнести тот факт, что нормы авторского права не рассматривают понятия «художественный стиль», «манера автора», то есть невозможность их охраны и защиты детально аргументирована в рамках законодательства.

Однако, стоит отметить, что сейчас есть теоретическая возможность охраны оригинального стиля (манеры) художника нормами патентного права. Например, получение патента на полезную модель «способ нанесения изображения на ровную поверхность». Патент это юридический документ, выданный государством, дающий изобретателю исключительное право на изготовление, использование и продажу изобретения в течение определенного периода времени. Патенты также выдаются на значительные улучшения в ранее изобретенных изделиях. Цель патентной системы состоит в том, чтобы поощрять изобретателей в продвижении вперед состояния техники путем предоставления им специальных прав, чтобы они могли извлечь выгоду из своих изобретений [3]. Книги, фильмы и произведения искусства не подлежат патентоспособности, но их можно защитить в соответствии с законом об авторском праве.

Патентное право сосредоточено вокруг понятия новизны и изобретательского уровня. Право, которое они предоставляют, препятствует всем другим, не только подражателям, но даже независимым разработчикам той же идеи, использовать изобретение в течение срока действия патента.

А может быть, результаты патентного поиска аналогов дадут возможность запатентовать изобретение с мировой новизной этого способа. Ведь творческая манера художника обязательно включает особенности его живописной техники. Наверное, мастера эпохи Возрождения, будь у них возможность патентовать свои новаторские находки в части состава красок, лаков, способа нанесения их на полотна, обогатились бы сказочно. А Леонардо за живописный прием «сфумато», использование законов пространственной перспективы и другие инновации стал бы владельцем «фабрики изобретений», опередив Эдисона, да и все человечество, на четыре столетия. Однако, в современных реалиях, при защите прав художника нормами патентного права возникнет необходимость в сложной экспертизе, доказывающей использование нарушителем именно запатентованного способа получения изображений. Поэтому этот вариант остается лишь в статусе теоретически возможного.

Помимо всего этого, лучшим способом защиты и охраны произведений искусства может быть добавление 
к ним уведомления об авторских правах, чтобы каждый знал, что такие произведения защищены авторским правом. Однако этот шаг будет эффективен только для законопослушных людей, но не для непослушных. Поэтому крайне важно со стороны создателя или его агента немедленно обратиться в суд при обнаружении любого нарушения авторского права на произведение.
Таким образом, считаем, что индивидуальный художественный стиль должен обрести нормативное закрепление в качестве объекта интеллектуальной собственности как один из основополагающих критериев идентификации истинности изделий художественных промыслов, обеспечивающих их признание в качестве произведения искусства.

\section{ЛИТЕРАТУРА}

1. Гражданский кодекс Российской Федерации (часть четвертая) от 18.12.2006 N230-Ф3 (ред. от 30.04.2021) // СПС Консультант Плюс

2. Айзенштейн А.К. Стиль в искусстве / А.К. Ай-зенштейн. — М.: Высшая школа, 2006. — 198 с.

3. Гришаев С.П. Интеллектуальная собственность: Учебное пособие. М.: Юрист, 2009.— 258 с.

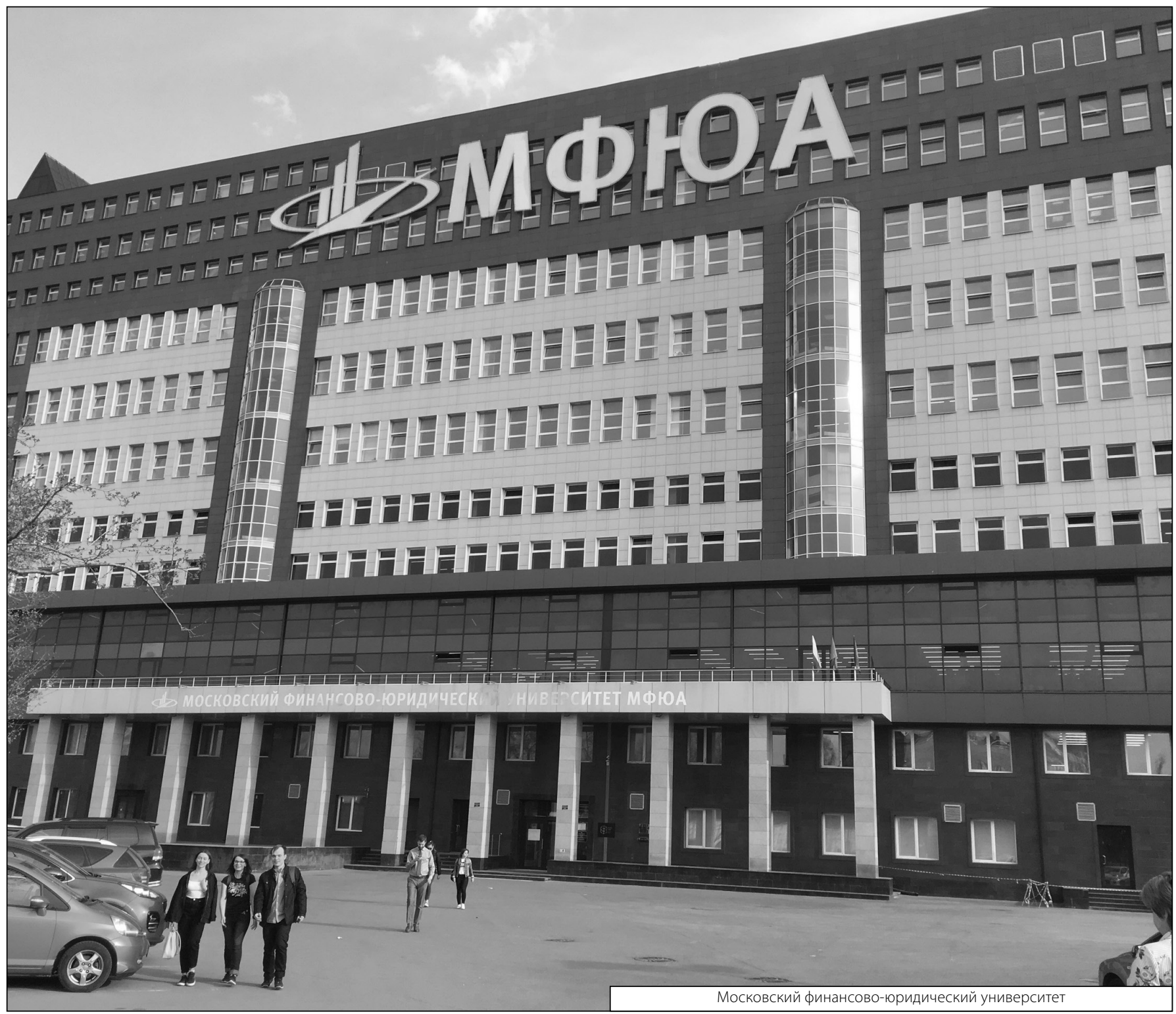

